\title{
Adaptation of Norway spruce populations in Europe: a case study from northern Poland ${ }^{s}$
}

\author{
Marcin Klisz ${ }^{*}$ DD, Szymon Jastrzębowski ${ }^{1}$, Krzysztof Ukalski ${ }^{2}$, Joanna Ukalska ${ }^{2}$ and Paweł Przybylski ${ }^{1}$
}

\begin{abstract}
Background: The productive potential of European species of forest tree assumes particular importance in the context of populations adapting to accelerating climatic change. Genotype-environment interaction $(\mathrm{G} \times \mathrm{E})$ was studied to determine Picea abies (L.) H.Karst. (Norway spruce) inter-population variation, characterising their adaptability to the growing conditions in north-eastern Poland. The data were analysed from 22 populations evaluated in four experimental sites based on 5-year height. To identify best-adapted as well as specifically adapted populations, GGE biplots were performed.

Findings: Analysis of multi-environment trial (MET) data revealed significant differences between four experimental sites, as well as interactions between populations and sites. However, it proved possible to identify specifically adapted populations achieving high values for the trait at specific sites only, although some performed relatively well across several sites.
\end{abstract}

Conclusions: The productive potential of the Norway spruce populations in north-eastern Poland is associated with specific adaptation of given populations to growth conditions at the experimental sites. However, in the set of populations studied can also be found some capable of average but stable growth in all experimental sites.

Keywords: Picea abies, GGE biplot, Genotype x environment interaction, Stability, Multi-environment trials, Growth rate, Adaptation

\section{Findings Introduction}

The observed increase in the rate of climate change and accompanying weather anomalies in Europe necessitate ongoing adaptation processes in forest trees, as well as generating changes in the productive potential of stands (Hanewinkel et al. 2012; IPCC 2015; Lindner et al. 2014). The adaptability of trees to new conditions is dependent on genetic diversity, which is largely controlled by population size, the nature and direction of observed climate change, and the direction and intensity of selection (Alberto et al. 2013). Among Europe's native tree species, Picea abies (L.) H.Karst. (Norway spruce) is characterised by broad

\footnotetext{
* Correspondence: m.klisz@ibles.waw.pl

$\S$ Based on a paper presented at the Forest Genetics for Productivity conference that was held in Rotorua, New Zealand, March 14-18, 2016. ${ }^{1}$ Department of Silviculture and Genetics, Forest Research Institute, Braci Leśnej Street, No 3, Sękocin Stary, 05-090 Raszyn, Poland

Full list of author information is available at the end of the article
}

adaptability, including the potential to adjust to the predicted water deficit in Central Europe (Lévesque et al. 2013; Zang et al. 2014).

Many studies have considered the potential of Norway spruce populations to adapt to climate change (Ununger et al. 1988; Krajmerová et al. 2009; Kapeller et al. 2012; Nilsson et al. 2012; Ulbrichová et al. 2015). However, the level of knowledge of the productive potential of Polish populations of Norway spruce are still inadequate for forecasting capacity to adapt to foreseen climate change (Matras 2002, 2009).

The results of phylogenetic studies based on molecular markers suggest separate evolutionary origin of Polish populations of Norway spruce with southern populations descended from Alpine refugia while north-eastern populations are from Scandinavian refugia (Lewandowski and Burczyk 2002; Nowakowska 2009; Dering and Lewandowski 2009).

Evaluation of the genotype $\times$ environment interaction $(\mathrm{G} \times \mathrm{E})$ in a multi-environment trials (MET) makes it 
possible to characterise the genetic conditioning behind the productive potential of forest trees in relation to site conditions (Kang and Gauch 1996). The use of the GGE biplots (graphical method) in MET-based analysis allows the mostrepresentative sites to be identified. Their discriminating ability can also be defined, along with the genotypes best adapted to grow in groups of experimental sites (MET). In addition, it is possible to characterise the stability of genotypes with respect to traits studied, i.e. in terms of rankings or relative performances of genotypes (Yan and Kang 2002). Among the broad range of possible analyses, the methods presented to assess the $\mathrm{G} \times \mathrm{E}$ are being used more and more in METs involving forest tree species (Murillo 2001; Kim et al. 2008; Ding et al. 2008; Correia et al. 2010; Sixto et al. 2015; Ukalski and Klisz 2016; Zhao et al. 2016).

We attempted to assess the influence of genetic and site factors on the productive potential, as assayed by height and survival 5 years after field planting, of populations of Norway spruce from north-eastern Poland. The assessment of the $\mathrm{G} \times \mathrm{E}$ was made based on GGE biplots, with the data used concerning measurements of the heights of trees in the MET.

\section{Materials and methods Experimental design}

Twenty-two populations of Norway Spruce (21 from north-eastern and one from southern Poland) were sampled for a series of four field trials (Table 1), each using a randomised complete block design with four replicates. All populations studied are selected seed stands-phenotypically the best Norway spruce stands in north-eastern Poland. Incorporating population 1 (from southern Poland) alongside a group of north-eastern populations was intended to reference the performance of local populations against one from outside of the region, meaning that it served as an outgroup. Seed collection in each stand was done on 50 randomly selected trees in 2009, on transects with a minimum distance of $25 \mathrm{~m}$ between trees. However, the origin of the metapopulation (local or from foreign seed source) has not been ascertained by phylogenetic study. Seeds were collected from healthy trees in a year of heavy seed production. From each tree was collected no less than $1 \mathrm{~kg}$ of cones. It allowed gathering over $20 \mathrm{~g}$ seeds per tree, meaning at least $1 \mathrm{~kg}$ of seed per stand.

Table 1 Mean values and coefficients of variation (CV\%) of tree heights at the individual-tree level and survival in 22 populations of spruce at four experimental sites: CBL Czarna Bialostocka, CDW Czerwony Dwor, GOL Goldap, and SCB Szczebra Czarna sites

\begin{tabular}{|c|c|c|c|c|c|c|c|c|c|c|}
\hline \multirow[t]{2}{*}{ Population } & \multicolumn{5}{|c|}{ Mean height [cm] (CV [\%]) } & \multicolumn{5}{|c|}{ Mean survival [\%] } \\
\hline & $\overline{\mathrm{CBL}}$ & CDW & GOL & SCB & Across sites & $\overline{\mathrm{CBL}}$ & CDW & GOL & SCB & Across sites \\
\hline 1 & $99(28)$ & $106(30)$ & $127(32)$ & $89(34)$ & $107(35)$ & 70 & 49 & 62 & 61 & 62 \\
\hline 5801 & $108(25)$ & $92(33)$ & $113(27)$ & $98(32)$ & $103(30)$ & 81 & 94 & 88 & 83 & 86 \\
\hline 5802 & $114(38)$ & $102(29)$ & $121(32)$ & $83(31)$ & $106(37)$ & 82 & 63 & 79 & 70 & 74 \\
\hline 5821 & $97(28)$ & $97(28)$ & $116(31)$ & $84(37)$ & $100(33)$ & 85 & 67 & 90 & 67 & 78 \\
\hline 6429 & $126(30)$ & $93(32)$ & $122(34)$ & $85(41)$ & $109(37)$ & 83 & 84 & 89 & 68 & 81 \\
\hline 6522 & $123(31)$ & $101(30)$ & $105(28)$ & $89(34)$ & $106(33)$ & 88 & 73 & 87 & 68 & 79 \\
\hline 6523 & $131(30)$ & $98(30)$ & $112(32)$ & 87 (37) & $110(35)$ & 92 & 81 & 79 & 62 & 78 \\
\hline 6540 & $98(28)$ & $107(30)$ & $113(31)$ & $82(36)$ & 101 (33) & 83 & 87 & 86 & 66 & 80 \\
\hline 27102 & $123(34)$ & $95(28)$ & $108(32)$ & 75 (36) & $102(37)$ & 86 & 84 & 88 & 71 & 82 \\
\hline 32160 & $117(26)$ & $113(31)$ & $112(33)$ & $89(38)$ & $108(33)$ & 84 & 68 & 88 & 71 & 78 \\
\hline 33253 & $116(30)$ & $90(30)$ & $110(33)$ & $87(34)$ & $103(34)$ & 89 & 57 & 83 & 66 & 75 \\
\hline 33256 & $98(27)$ & $107(29)$ & 118 (34) & $78(35)$ & 101 (34) & 86 & 91 & 83 & 68 & 81 \\
\hline 33257 & $93(27)$ & $123(29)$ & $112(32)$ & $85(33)$ & 101 (34) & 73 & 47 & 92 & 70 & 72 \\
\hline 33259 & 99 (28) & $94(29)$ & 99 (33) & $82(34)$ & $94(32)$ & 80 & 76 & 75 & 66 & 74 \\
\hline 50257 & $111(34)$ & $96(29)$ & $120(30)$ & $80(34)$ & $104(35)$ & 86 & 82 & 92 & 66 & 81 \\
\hline 50258 & $136(31)$ & $104(29)$ & $121(30)$ & $81(30)$ & $112(36)$ & 88 & 87 & 87 & 74 & 83 \\
\hline 50262 & $117(40)$ & $106(31)$ & $124(29)$ & $82(35)$ & $110(37)$ & 85 & 85 & 90 & 54 & 78 \\
\hline 50263 & $119(34)$ & $92(31)$ & $106(37)$ & 79 (35) & $100(38)$ & 85 & 83 & 77 & 72 & 79 \\
\hline 50264 & $111(35)$ & 105 & 109 (33) & $78(32)$ & 101 (37) & 78 & 77 & 85 & 70 & 77 \\
\hline 50265 & $120(32)$ & $115(31)$ & $108(33)$ & $86(33)$ & $108(35)$ & 86 & 82 & 75 & 63 & 76 \\
\hline 52690 & $123(28)$ & $96(35)$ & 105 (32) & $84(33)$ & $104(34)$ & 91 & 84 & 86 & 70 & 82 \\
\hline 52692 & $137(28)$ & $115(27)$ & 119 (33) & $82(34)$ & 115 (35) & 82 & 88 & 80 & 62 & 72 \\
\hline Multi-population mean & $115(33)$ & $102(32)$ & $114(32)$ & $84(35)$ & $105(35)$ & 84 & 77 & 84 & 67 & 78 \\
\hline
\end{tabular}


The seedlings were produced in Kołaki Forest Nursery (N $53^{\circ} 18^{\prime}$, E $22^{\circ} 04^{\prime}$ ). Sowing was carried out manually in March 2010, one seed per container cell. For producing the seedlings, HIKO V120/40 containers were used (cell volume, $120 \mathrm{~cm}^{3} / 7.32 \mathrm{in}^{3}$ ). Seedlings were kept in polyhouses until June 2010 then they were transferred to open-air conditions. A late frost in April 2011 led to the death of a number of apical shoots so some seedlings were culled from the planting stock at the nursery stage. During all nursery stages, the containers were grouped on pallets with populations distributed randomly. Up to the planting stage, seedlings were not removed from the container in order to avoid mistakes between populations. After 1 year growing in the nursery, planting material was transferred directly to the experimental sites. To acclimatise the seedlings to local growing conditions, planting material was stored close to planting places.

Planting was done in 2011 in north-eastern Poland, at the four localities: Czerwony Dwór (CDW) (N 54 17' E

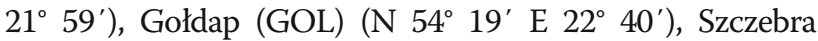
(SCB) (N 53 $56^{\prime} \mathrm{E} 22^{\circ} 54^{\prime}$ ) and Czarna Białostocka (CBL)

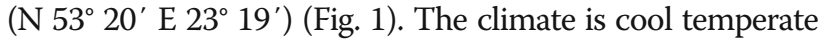
with a mean annual temperature from 6.8 to $7.4{ }^{\circ} \mathrm{C}$ (respectively: SCB, CDW) and annual precipitation from 569 to $582 \mathrm{~mm}$ (respectively: CDW, CBL), mostly distributed in June-November [climate data from National Oceanic and Atmospheric Administration (NOAA) agency, weather stations in Białystok, Suwałki and Kętrzyn, reference period
1973-2014] (NOAA/NCEI/CWC http://www.noaa.gov/)] (Fig. 2). The soils were loamy sand (SCB), spodic (CDW, $\mathrm{GOL})$, or rusty (CBL). The ground in all cases was previously occupied by managed forest stand dominated by 80 100-year-old trees of Pinus sylvestris L. (Scots pine) and Norway spruce. After clear-cutting a year earlier, the ground was cultivated 3 months before planting. The experimental sites were established using 10 -tree $\times 10$-tree population plots, at $1.5 \times 1.5 \mathrm{~m}$ spacing. In the $\mathrm{CBL}, \mathrm{GOL}$ and SCB sites, each test population was represented by 400 trees (100 per plot $\times$ four replicates) but in CDW by 300 trees (100 per plot $\times$ three replicates). Only population 1 was represented by 300, 200, 400 and 300 trees (respectively: CBL, CDW, GOL, SCB). The reference population (1) for the trials was the Istebna selected seed stand in southern Poland (N 49 34' E $18^{\circ} 50^{\prime}$ ). In 2015, following 5 years of growth, the heights of all surviving trees were measured in each site (Table 1).

\section{The impact of the environment and genotype on height growth}

According to a linear model with genotype and block fixed effects, analysis of variance was performed for each site separately. Based on Tukey HSD test, homogeneous groups were determined for the sites where the genotype effect was significant $(p<0.05)$.

The modelling approach in MET analysis is recently based on mixed model framework (Piepho 1998; Balzarini
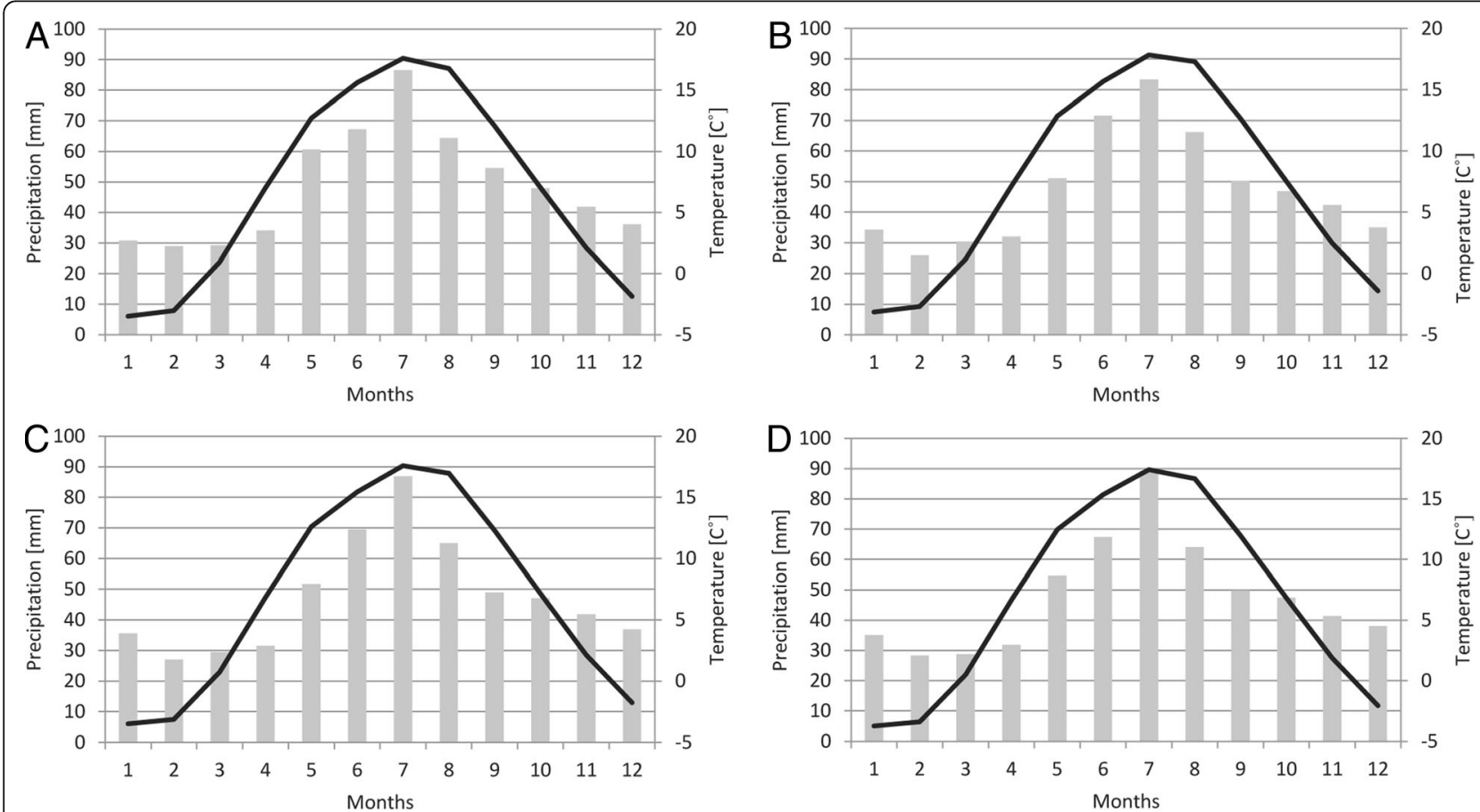

Fig. 1 The range of mean temperature and sum of precipitation for study sites. Graphs: a Czarna Bialostocka, b Czerwony Dwor, c Goldap, d Szczebra. Black line - mean monthly temperature, grey bars — sum of monthly precipitation 


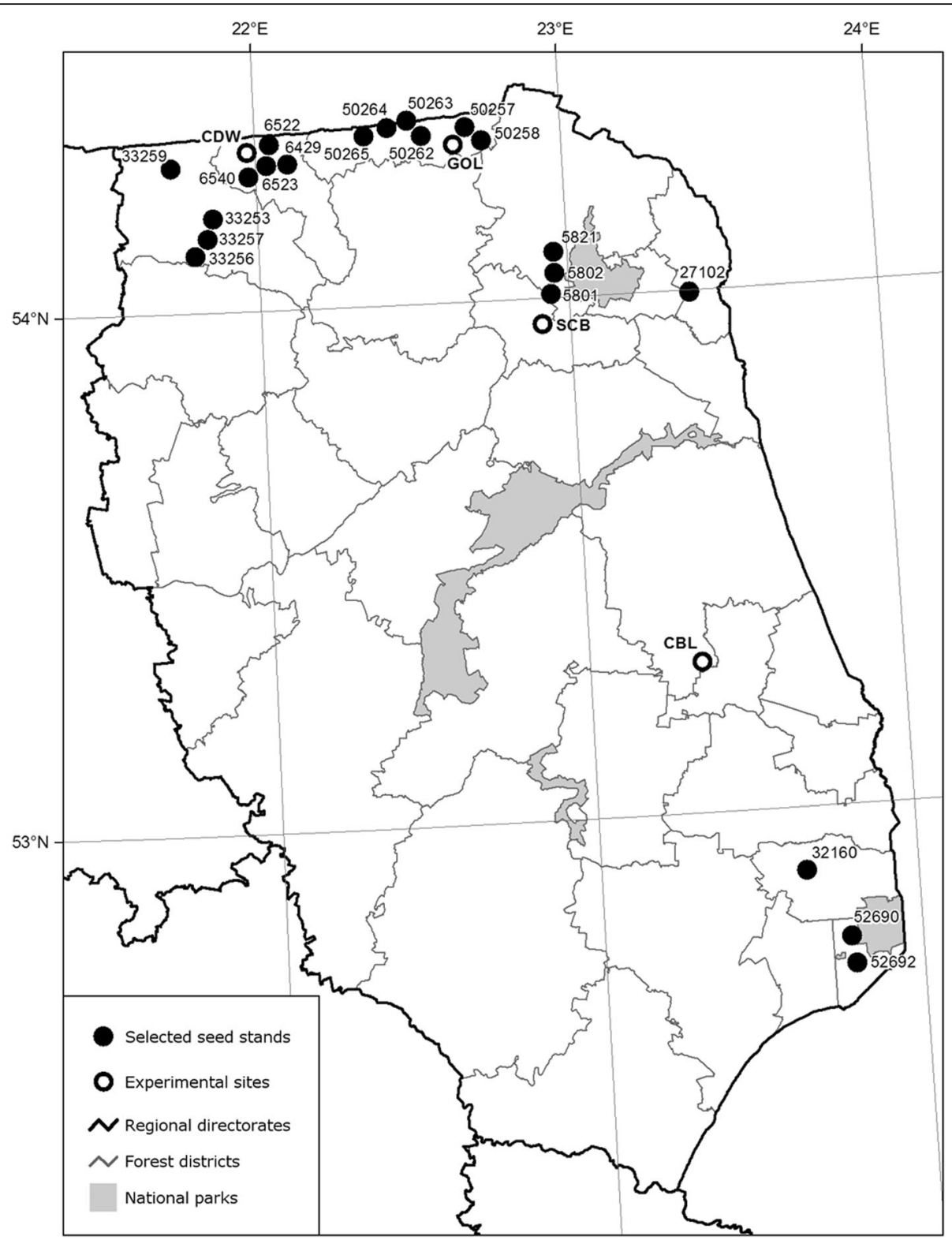

Fig. 2 Locations of study sites. CDW Czerwony Dwor, GOL Goldap, SCB Szczebra, CBL Czarna Bialostocka experimental sites; 5801, 5802, 5821, 6429, 6522, 6523, 6540, 27102, 32160, 33253, 33256, 33257, 33259, 50257, 50258, 50262, 50263, 50264, 50265, 52690, 52692-tested populations. Grey line-boundaries of forest districts

2002). Environments are deemed to be a random effect, as they were chosen to represent a roughly random sample of a population of environments. The effect of genotypes is often treated as a fixed effect, in that the genotypes may represent the entire population in a genetic improvement programme. When at least one of the two main factor effects is regarded as random, the $\mathrm{G} \times \mathrm{E}$ interaction effect is also deemed to be random (Saxton 2004). On this basis, we fitted a linear mixed model for classifying the effects site, population, block and $\mathrm{G} \times \mathrm{E}$ interaction, in the following form (Searle et al. 1992, Piepho 1998):

$$
y_{i j k}=\mu+r_{k}\left(e_{j}\right)+g_{i}+e_{j}+g e_{i j}+\varepsilon_{i j k}
$$

where $y_{i j k}$ is the trait value observed for the experimental plot for the $i$ th genotype $(i=1, \ldots, G)$ in the $j$ th site $(j=$ $1, \ldots, E)$ and in the $k$ th block $(k=1, \ldots, R), \mu$ is the general mean, $g_{i}$ is the fixed effect of the $i$ th genotype, $e_{j}$ is the random effect of the $j$ th site, $g e_{i j}$ is the random effect of the genotype $\times$ site interaction, $r_{k}\left(e_{j}\right)$ is the random effect of the $k$ th block in the $j$ th site, and $\varepsilon_{i j k}$ is the random residual containing the effect of a block-within-site $x$ genotype interaction (i.e. plot effect) and some tree- 
within-plot experimental error. The data obtained for the 22 spruce populations at the four sites did not represent a fully balanced classification. The best linear unbiased predictors (BLUP) were calculated to create, in effect, a completed data set (Piepho 1998; Balzarini 2002; Piepho and Möhring 2006; Piepho et al. 2008). F statistics for testing random effects were determined using the Hocking's approach (Hocking and Speed 1975).

\section{GGE and GREG biplots}

To identify stable populations in terms of height growth at the experimental sites, the GGE biplot was used (Gabriel 1971; Yan et al. 2001). The significance of the individual $\mathrm{G} \times \mathrm{E}$ interaction effects was examined using the Bonferonni test (Dunn 1961), with a 0.01 probability threshold experiment-wise. In turn, GREG biplot (Cornelius et al. 1996; Cornelius and Seyedsadr 1997) was used to determine the similarity between sites, along with the AEC method (Yan and Hunt 2001; Yan 2002). The choice of the GREG biplot was dictated by the fact that first and second principal components for interaction effects (PC1 and $\mathrm{PC} 2$, respectively) explained 9.95\% more of the variation than did the GGE biplot, as well as the fact that the interaction in this model comprises the effects of $E$ and the $G \times E$, a combination that better characterises the interrelationships between the experimental sites (Ukalski and Klisz 2016).

The similarities between all of the pairs of experimental sites were determined in two ways. In the first method, the value of $\alpha_{\mathrm{ij}}$ angles between vectors $\mathrm{OA}_{\mathrm{i}}$ and $\mathrm{OB}_{j}$ were determined (where $\mathrm{OA}_{i}$ and $\mathrm{OB}_{j}$ are vector lengths between the centre of the coordinate system and position of sites $\mathrm{A}$ and $\mathrm{B}$, respectively). In the second method, Pearson correlation coefficients were calculated for each pair of sites on the basis of the principal component values utilising $\mathrm{G} \times \mathrm{E}$ interaction effects.

Statistical analyses and presented biplots were performed using SAS/STAT 13.1 software (SAS Institute Inc 2013) with procedures GLM, MIXED (Littell et al. 1996), PRINCOMP (Khattree and Naik 2000), and GPLOT.

\section{Results and discussion \\ Analysis of variance}

Between-population differences were confirmed for height growth only for the CDW site, while for survival only for the CDW and GOL sites. Details regarding the analyses of variance are given in Additional file 1: Table S1.

For height growth, no significant across-site differentiation among the populations was found but there was strong among-site variation as well as a $G \times E$ interaction (Table 2). The $F$ value for genotype effect was less than 1 , because $\mathrm{Q}(\mathrm{G})<0$ for the quadratic form associated with the genotype fixed effect. This meant the estimate of the genotypic variance across sites was negative, so we assumed the variance to be zero. Accordingly, we found that the overall variation in height was explained by the effects of site (E) (72\%) and $\mathrm{G} \times \mathrm{E}$ interaction (28\%). Low variation explained by the across-site genotype effect may be related to modest local genetic variation within the Norway spruce metapopulations of northeastern Poland (Lewandowski and Burczyk 2002). However, it is still surprising in the context of the modest variation of environmental conditions among the experimental sites (low in the case of climatic conditions and modest in the case of soil). The aforementioned results are in accordance with the results of ANOVA performed at the individualpopulation level separately for each site (Additional file 1 : Table S1). Significance of genotypic variation and of $\mathrm{G} \times \mathrm{E}$ had been demonstrated previously in research on tested clones of Norway spruce from central and southern Sweden (Bentzer et al. 1988), as well as in work involving Japanese red pines (Pinus densiflora Siebold \& Zucc.) in South Korea (Kim et al. 2008). Studies of European provenances of Norway spruce carried out in 11 localities in northern Denmark and southern Sweden pointed stability in all the test environments (Karlsson et al. 2001).

The principal components analysis (PCA) showed that the division of effects $(G+E+G E)$ with GGE biplot was as follows: the PC1 explained $51.08 \%$ of the variation $(\mathrm{G}+\mathrm{E}+$ GE), while PC2 explained $25.85 \%$. This made $76.93 \%$ in total.

\section{Similarity of environments}

Use of principal components $\mathrm{PC} 1$ and $\mathrm{PC} 2$ for the four sites allowed for the designation of the average environment (AE). This was then used, in association with the centre of the coordinate system, to run an AE axis (Fig. 3).

The location of sites relative to the position of the $\mathrm{AE}$ axis shows that the average height of spruce trees at CDW was almost identical to the height overall mean. Where the comparisons among the other sites were concerned, two-SCB and GOL-were rotated through $90^{\circ}$ in the direction of the location of site CBL. A new AE point for these three sites was designated. It emerged that, at the CBL site, the heights of spruce trees were greater than the overall mean, as was also the case for the GOL site, albeit with the differences in comparison with the mean being slight in this case. In contrast, at the SCB site, heights of spruce trees were much below the overall mean.

The vector length of the site is determined by a line drawn through the biplot origin and the site marker and is a measure of discriminating ability of the site. Thus, the sites CBL and CDW, which had the longest vectors, were the most discriminating for genotypes. The line that passes through the plot origin and is perpendicular to the $\mathrm{AE}$ axis is a measure of representativeness of the sites (Yan and Hunt 2001). Therefore, site CDW was the most representative (as it had a near-zero length of projection from marker of a site onto the $\mathrm{AE}$ axis) and $\mathrm{CBL}$ was the least. 
Table 2 Results of analysis of variance for tree heights in 22 populations of spruce at four trial sites, along with the percentage of the variation explained $(\mathrm{Q}(\mathrm{G})$ is a quadratic form associated with genotype fixed effect; F statistics are calculated according to Hocking's approach)

\begin{tabular}{|c|c|c|c|c|c|c|c|}
\hline Source of variation & $\mathrm{df}$ & Mean square & Expected mean square & Error term & $\mathrm{F}$ & $P$ & $\%(G+E+G E)$ \\
\hline Genotype (G) & 21 & 248.34 & $\operatorname{Var}($ ERROR $)+3.69 \operatorname{Var}(\mathrm{GE})+\mathrm{Q}(\mathrm{G})$ & $0.989 * \mathrm{MS}(\mathrm{GE})+0.011^{*} \mathrm{MS}(\mathrm{ERROR})$ & 0.81 & 0.700 & 0 \\
\hline Site $(E)$ & 3 & 16,825 & $\begin{array}{l}\operatorname{Var}(\text { ERROR })+3.73 \operatorname{Var}(\mathrm{GE})+ \\
22 \operatorname{Var}(\text { Block }(\text { Site }))+82.13 \operatorname{Var}(\mathrm{E})\end{array}$ & $\begin{array}{l}\text { MS(Block (Site)) + } \\
\text { MS(GE) - MS(ERROR) }\end{array}$ & 6.9 & 0.006 & 72 \\
\hline Block (site) & 11 & 2339.99 & $\operatorname{Var}($ ERROR $)+22 \operatorname{Var}($ Block (Site)) & MS(ERROR) & 11.12 & $<0.001$ & - \\
\hline Genotype × site (GE) & 63 & 309.44 & $\operatorname{Var}($ ERROR $)+3.73 \operatorname{Var}(G E)$ & MS(ERROR) & 1.47 & 0.020 & 28 \\
\hline Experimental error (ERROR) & 231 & 210.49 & $\operatorname{Var}(E R R O R)$ & & & & \\
\hline
\end{tabular}

On the basis of the comparison of angles between vectors for the sites, it was noted that the sites most similar to each other were GOL and SCB (Fig. 2). Location of CBL site in the diagram suggests that the Norway spruce genotypes show the opposite interaction $(\mathrm{G} \times \mathrm{E})$ than $\mathrm{GOL}$ and $\mathrm{SCB}$ sites. The vector for site CDW creates obtuse angles with the others, albeit ones close to right angles (Fig. 3); while the correlation coefficients indicate non-significant correlation with the remaining three sites (Table 3).

\section{Stability of populations}

The GGE biplot (Fig. 4) was used to define the population of spruce at each site characterised by the greatest effect of $\mathrm{G} \times \mathrm{E}$. The GGE biplot has a polygon formed through the connection of the positions of populations located furthest from the centre of the coordinate system. All remaining populations are contained within the polygon created. The lines creating the sectors are at right angles to the sides of the polygon or else form extensions of them (Yan 2001). The 22 populations of spruce and four sites are found to be distributed across seven sectors. Sites CDW and GOL fall within a single sector. A high mean for height at these two sites characterised population 33257, which at the same time showed marked instability. In turn, at site CDW, population 33257 attained very superior heights, though it achieved only very low ones at site CBL. It was in a second sector containing population 52692 that site CBL was located. There, the latter population, with its good growth,

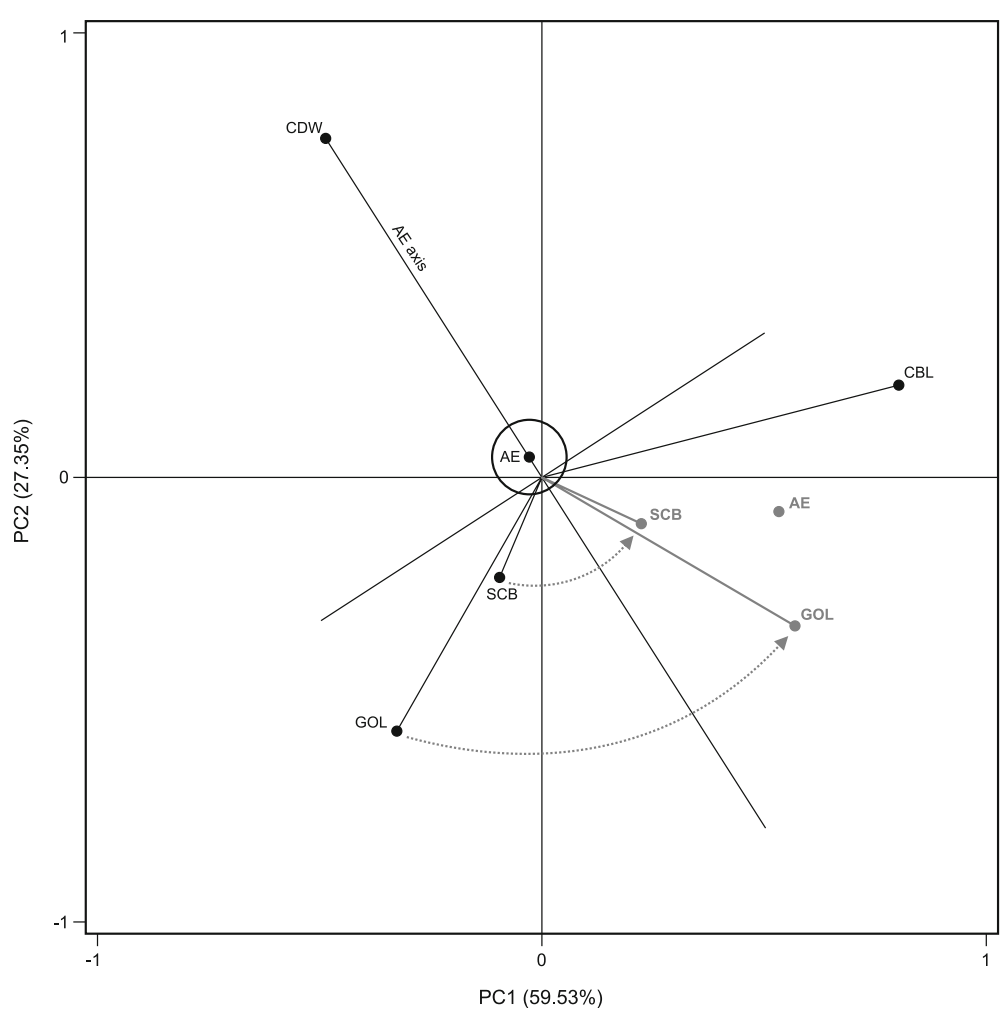

Fig. 3 View of AEC on the GREG-type biplot based on principal components for the environments. AE in the circle is the 'average environment' for SCB, GOL and CBL designated for comparison 
Table 3 Correlation coefficients (upper triangle in the table) and $a_{i j}$ angles (lower triangle) for pairs of sites as of 2010

\begin{tabular}{lllll}
\hline Sites & CBL & CDW & GOL & SCB \\
\hline CBL & & $-0.31 \mathrm{~ns}$ & $-0.71^{* *}$ & $-0.63^{* *}$ \\
CDW & 108 & & $-0.46 \mathrm{~ns}$ & $-0.54 \mathrm{~ns}$ \\
GOL & 135 & 117 & & $0.99^{* *}$ \\
SCB & 129 & 123 & 5.75 & \\
\hline
\end{tabular}

**Significant at the 0.01 probability level, $n s$ not significant, degrees of freedom $=20$

was joined by populations 50258 and 6523, among which tree heights were also good. Population 50265 also attained good heights at CBL, while at the same time being characterised by a strong interaction with CDW (a positive effect of $\mathrm{G} \times \mathrm{E}$ ) and with GOL (a negative effect of $\mathrm{G} \times \mathrm{E}$ ). It was in a third sector designated by population 6429 that site SCB was present. These relationships may be summarised by the occurrence of populations characterised by aboveaverage values for mean height at specific sites only, i.e. the trait is unstable at a population level. It is also possible to distinguish populations that are average for height, if resilient with respect to variable conditions of growth (in different sites). A similar ranking of genotypes for stability and the mean value for a feature was presented by Zhao et al. (2016) in their research on Betula platyphylla Sukaczev. A further polygon contains the remaining interactions of populations at other experimental sites. Population 5821 is characterised by a high negative interaction with site CBL, population 33259 by a high negative interaction with sites CDW and GOL, population 33253 by a large negative interaction with site CDW, and population 5801 by a high positive interaction with site SCB. The group of unstable populations (with large absolute $\mathrm{PC} 2$ values) characterised by large values for heights ( $\mathrm{PC1}$ values) contains populations 52692, 50258 and 6429, while the unstable group with low values comprises of populations 33257, 5821 and 33259 (Fig. 5). Stable populations (with absolute PC2 values close to 0 ) that are also tall are 6523 and 6522, while the stable population with low tree heights are populations 1 and 6540 . Stable poor performance of southern population 1 does not seem to be surprising in view of its 'outgroup status'. Perhaps good adaptation of this population to the growing conditions prevailing in the mountains (Beskidy Mountain) does not fit with the continental conditions in north-eastern Poland. The specific adaptation of population 52692 from Białowieża Forest to growth in experimental sites CBL and CDW seems to be interesting, in the context of other phylogenetic analyses describing the Białowieża population as different from the other Northern population (Dering and Lewandowski 2009).

\section{Conclusions}

Most of the observed variation among populations is explained by the $G \times E$ rather than across-site main effects of populations. The growth potential of the northern populations shows no clear geographical trend. Population 52692 from Białowieża Forest shows specific

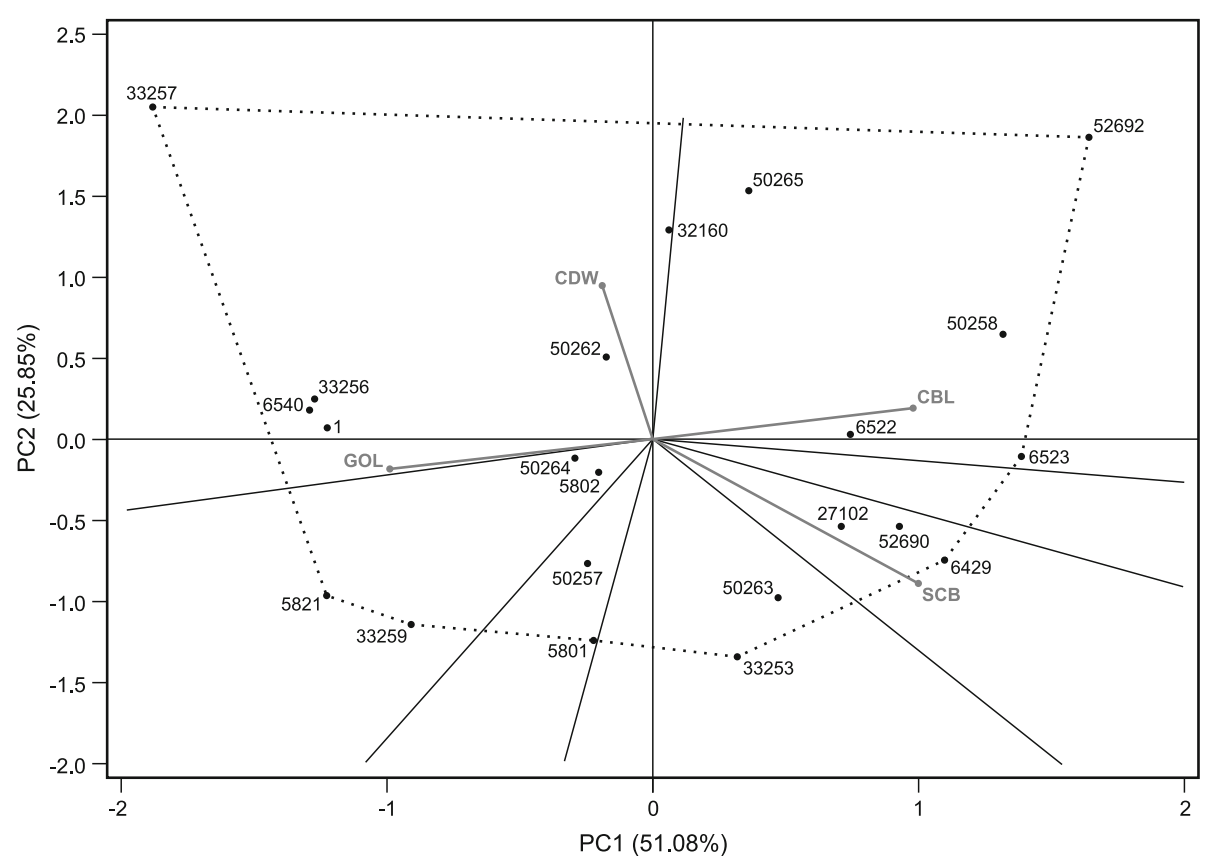

Fig. 4 The polygon on the GGE biplot formed from values for principal components useful in assigning the populations and four sites to sectors, on the basis of locations most distant from the centre of the coordinate system for genotypes 


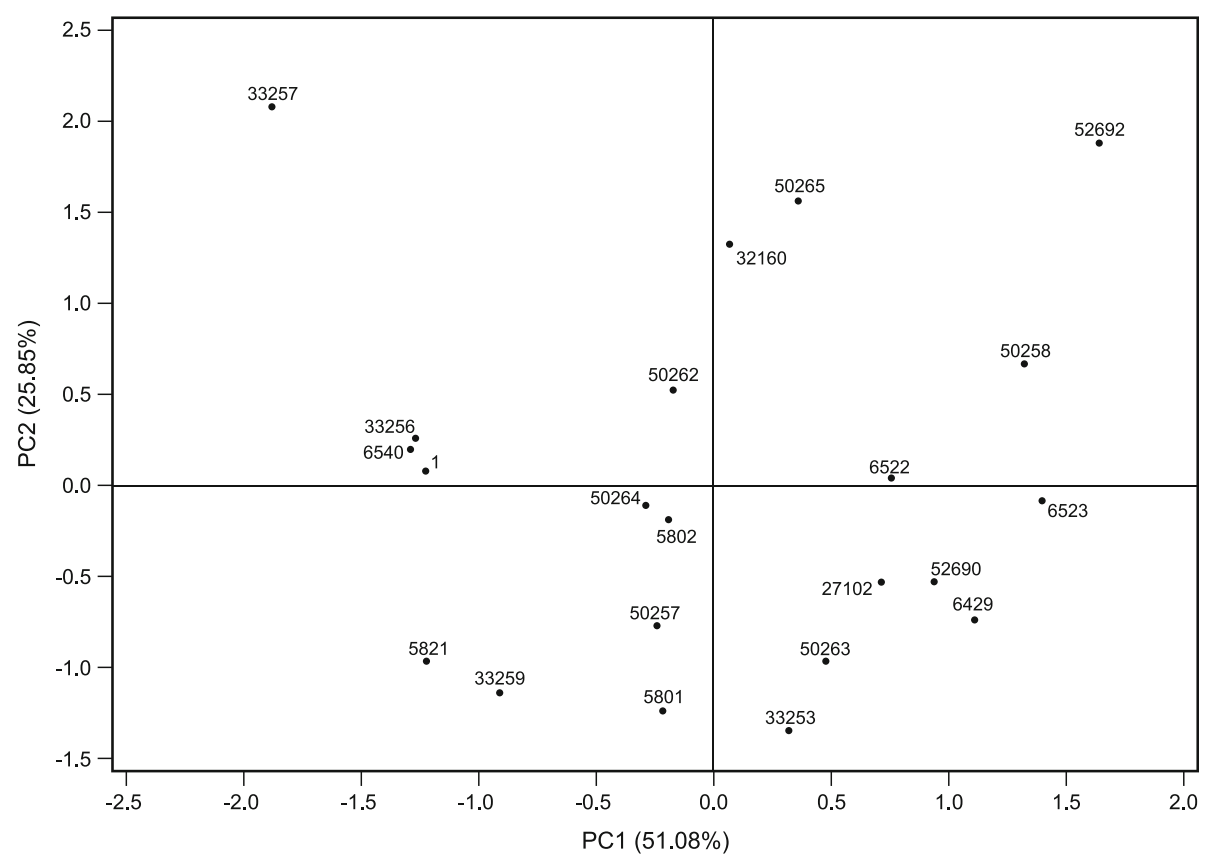

Fig. 5 Distribution of genotypes on the GGE-type biplot. Principal component PC1 describes height, while PC2 describes the size of the GE interaction

adaptation to growth at experimental sites $\mathrm{CBL}$ and CDW. Population 1 (national standard from southern Poland) shows some lack of adaptation to the growing conditions in northern Poland. Site CDW seems to be the most-representative site, while $\mathrm{CBL}$ and $\mathrm{SCB}$ are characterised by the greatest discriminating ability.

\section{Additional file}

Additional file 1: Table S1. Mean plot values of tree heights and survival in 22 populations of spruce at four experimental sites: CDW - Czerwony Dwor, GOL - Goldap, SCB - Szczebra, CBL - Czarna Bialostocka sites. ANOVA was performed for each site separately. Homogeneous groups were determined based on Tukey HSD test. Means with the same letter within the column are not significantly different at $p<0.05$. (DOCX $20 \mathrm{~kb}$ )

\section{Abbreviations}

AE: Average environment; AEC: Average environment coordination; BLUP: Best linear unbiased predictor; CBL: Czarna Białostocka experimental site; CDW: Czerwony Dwór experimental site; E: Effect of environment; G: Effect of genotype; GXE: Genotype-environment interaction; GGE: Genotype and genotype-by-environment interaction biplot; GOL: Gołdap experimental site: GREG: Genotype regression biplot; MET: Multi-environment trial; PC: Principal components; PC1: First principal component; PC2: Second principal component; PCA: Principal components analysis; SCB: Szczebra experimental site

\section{Acknowledgements}

The study was funded by the State Forests National Forest Holding as part of research project BLP-375. The authors are grateful to Dr Rowland Burdon for his insightful comments helping to make this a stronger manuscript.

\section{Authors' contributions}

MK is responsible for the data collection, preparation of manuscript, text corrections, coordinating work; Sz is responsible for the initial preparation, data collection, text corrections; $\mathrm{KU}$ is responsible for the proposal and performance of statistical analysis and contribution to interpretation of results; $J U$ is responsible for the description and performance of statistical analysis and correction of manuscript; PP is responsible for the data collection, text corrections. All authors read and approved the final manuscript.

\section{Competing interests}

The authors declare that they have no competing interests.

\section{Author details}

'Department of Silviculture and Genetics, Forest Research Institute, Braci Leśnej Street, No 3, Sękocin Stary, 05-090 Raszyn, Poland. 'Biometry Division, Department of Econometrics and Statistics, Faculty of Applied Informatics and Mathematics, Warsaw University of Life Sciences, 02-776 Warsaw, Poland.

Received: 28 April 2016 Accepted: 13 February 2017

Published online: 07 March 2017

\section{References}

Alberto, F. J., Aitken, S. N., Alía, R., González-Martínez, S. C., Hänninen, H., Kremer, A., et al. (2013). Potential for evolutionary responses to climate change-evidence from tree populations. Global Change Biology, 19(6), 1645-1661. doi:10.1111/gcb.12181.

Balzarini, M. (2002). Applications of mixed models in plant breeding. In M. S. Kang (Ed.), Quantitative genetics, genomics, and plant breeding (pp. 353-365). New York: CABI Publishing.

Bentzer, B. G., Foster, G. S., Hellberg, A. R., \& Podzorski, A. C. (1988). Genotype X environment interaction in Norway spruce involving three levels of genetic control: seed source, clone mixture, and clone. Canadian Journal of Forest Research, 18(9), 1172-1181. doi:10.1139/x88-180.

Cornelius, P. L. \& Seyedsadr, M. S. (1997). Estimation of general linear-bilinear models for two-way tables. Journal of Statistical Computation and Simulation, 58(4), 287-322. doi:10.1080/00949659708811837.

Cornelius, P. L., Crossa, J., \& Seyedsadr, M. (1996). Statistical tests and estimators of multiplicative models for cultivar trials. In M. S. Kang \& H. G. Gauch Jr. (Eds.), Genotype- by-Environment Interaction (pp. 199-234). Boca Raton: CRC Press.

Correia, I., Alia, R., Yan, W., David, T., Aguiar, A., \& Almeida, M. H. (2010). Genotype $\times$ Environment interactions in Pinus pinaster at age 10 in a multienvironment trial in Portugal: a maximum likelihood approach. Annals of Forest Science, 67(6), 612p1-612p9. doi:10.1051/forest/2010025. 
Dering, M., \& Lewandowski, A. (2009). Finding the meeting zone: where have the northern and southern ranges of Norway spruce overlapped? Forest Ecology and Management, 259, 229-235. doi:10.1016/j.foreco.2009.10.018.

Ding, M., Tier, B., Yan, W., Wu, H. X., Powell, M. B., \& McRae, T. A. (2008). Application of GGE biplot analysis to evaluate Genotype (G), Environment (E), and $G \times E$ interaction on Pinus radiata: a case study. New Zealand Journal of Forestry Science, 38(1), 132-142.

Dunn, O. J. (1961). Multiple comparisons among means. Journal of the American Statistical Association, 56(293), 52-64. doi:10.1080/01621459.1961.10482090.

Gabriel, R. K. (1971). The biplot graphic display of matrices with application to principal component analysis. Biometrika, 58(3), 453-467. doi:10.1093/biomet/ 58.3.453.

Hanewinkel, M., Cullmann, D. a., Schelhaas, M.-J., Nabuurs, G.-J., \& Zimmermann, N. E. (2012). Climate change may cause severe loss in the economic value of European forest land. Nature Climate Change, 3(3), 203-207. doi:10.1038/nclimate1687.

Hocking, R. R., \& Speed, F. M. (1975). A full rank analysis of some linear model problems. Journal of the American Statistical Association, 70(351), 706-712. doi:10.2307/2285959.

IPCC. (2015). In Core Writing Team, R. K. Pachauri, \& L. A. Meyer (Eds.), Climate Change 2014: Synthesis Report. Contribution of Working Groups I, II and III to the Fifth Assessment Report of the Intergovernmental Panel on Climate Change. Geneva: IPCC.

Kang, M. S., \& Gauch, H. G. (1996). Genotype-by-Environment Interaction. London: CRC Press. doi:10.1201/9781420049374.fmatt.

Kapeller, S., Lexer, M. J., Geburek, T., Hiebl, J., \& Schueler, S. (2012). Intraspecific variation in climate response of Norway spruce in the eastern Alpine range: selecting appropriate provenances for future climate. Forest Ecology and Management, 271, 46-57. doi:10.1016/j.foreco.2012.01.039.

Karlsson, B., Wellendorf, H., Roulund, H., \& Werner, M. (2001). Genotype x trial interaction and stability across sites in 11 combined provenance and clone experiments with Picea abies in Denmark and Sweden. Canadian Journal of Forest Research, 31(10), 1826-1836. doi:10.1139/cjfr-31-10-1826.

Khattree, R., \& Naik, D. N. (2000). Multivariate Data Reduction and Discrimination with SAS Software. Cary: SAS Institute Inc.

Kim, I. S., Kwon, H. Y., Ryu, K. O., \& Wan, Y. C. (2008). Provenance by site interaction of Pinus densiflora in Korea. Silvae Genetica, 57(3), 131-139.

Krajmerová, D., Longauer, R., Pacalaj, M., \& Gömöry, D. (2009). Influence of provenance transfer on the growth and survival of Picea abies provenances. Dendrobiology, 61(SUPPL. 1), 17-23.

Lévesque, M., Saurer, M., Siegwolf, R., Eilmann, B., Brang, P., Bugmann, H., \& Rigling, A. (2013). Drought response of five conifer species under contrasting water availability suggests high vulnerability of Norway spruce and European larch. Global Change Biology, 19(10), 3184-3199. doi:10.1111/gcb.12268.

Lewandowski, A., \& Burczyk, J. (2002). Allozyme variation of Picea abies in Poland. Scandinavian Journal of Forest Research, 17(6), 487-494. doi:10.1080/ 02827580260417134 .

Lindner, M., Fitzgerald, J. B., Zimmermann, N. E., Reyer, C., Delzon, S., Van Der Maaten, E., et al. (2014). Climate change and European forests: what do we know, what are the uncertainties, and what are the implications for forest management? Journal of Environmental Management, 146, 69-83. doi:10. 1016/j.jenvman.2014.07.030

Littell, R. C., Milliken, G. A., Stroup, W. W., \& Wolfinger, R. D. (1996). SAS System for Mixed Models. Cary: SAS Institute Inc.

Matras, J. (2002). Growth and development of polish provenances of Norway spruce (Picea abies Karst.) in the IUFRO 1972 experiment. Forest Research Papers, 947(4), 73-97. https://www.ibles.pl/web/lesne-prace-badawcze/-/ prace-instytutu-badawczego-lesnictwa-a-2002-4-73-97.

Matras, J. (2009). Growth and development of Polish provenances of Norway spruce (Picea abies Karst.) in the IUFRO 1972 experiment. Dendrobiology, 61, $145-158$.

Murillo, O. (2001). Genotype by environment interaction and genetic gain on unbalanced Pinus oocarpa provenances trials. Agronomia Costarricense, 25(1), 21-31.

Nilsson, U., Elfving, B., \& Karlsson, K. (2012). Productivity of Norway spruce compared to Scots pine in the interior of Northern Sweden. Silva Fennica, 46(2), 197-209.

Nowakowska, J. A. (2009). Mitochondrial and nuclear DNA differentiation of Picea abies populations in Poland. Dendrobiology, 61(SUPPL. 1), 119-129.

Piepho, H. P. (1998). Empirical best linear unbiased prediction in cultivar trials using factor-analytic variance structures. Theoretical and Applied Genetics, 97(1-2). 195-201. doi:10.1007/s001220050885.
Piepho, H. P., \& Möhring, J. (2006). Selection in cultivar trials-is it ignorable? Crop Science, 46(1), 192-201. doi:10.2135/cropsci2005.04-0038.

Piepho, H. P., Möhring, J., Melchinger, A. E., \& Büchse, A. (2008). BLUP for phenotypic selection in plant breeding and variety testing. Euphytica, 161, 209-222. doi:10.1007/s10681-007-9449-8.

SAS Institute Inc. (2013). SAS/STAT 13.1 User's Guide. Cary: SAS Institute Inc.

Saxton, A. M. (2004). Genetic Analysis of Complex Traits Using SAS (pp. 1-292). Cary: SAS Institute Inc.

Searle, S. R., Casella, G., \& McCulloch, C. E. (1992). Variance Components (pp. 1537). New York: John Wiley and Sons.

Sixto, H., Gil, P. M., Ciria, P., Camps, F., Cañellas, I., \& Voltas, J. (2015). Interpreting genotype by environment interaction for biomass production in hybrid poplars under short rotation coppice in Mediterranean environments. GCB Bioenergy. doi:10.1111/gcbb.12313.

Ukalski, K., \& Klisz, M. (2016). Application of GGE biplot graphs in multienvironment trials on selection of forest trees. Folia Forestalia Polonica Series A-Forestry, 58(4), 228-239. doi:10.1515/ffp-2016-0026.

Ulbrichová, I., Podrázský, V., Beran, F., Zahradník, D., Fulín, M., Procházka, J., \& Kubeček, J. (2015). Picea abies provenance test in the Czech Republic after 36 years - Central European provenances. Journal of Forest Science, 61(11), 465477. doi: 10.17221/23/2015-JFS.

Ununger, J., Ekberg, I., \& Kang, H. (1988). Genetic control and age-related changes of juvenile growth characters in Picea abies. Scandinavian Journal of Forest Research, 3, 55-66. doi:10.1080/02827588809382495.

Yan, W., Cornelius, P. L., Crossa, J., \& Hunt, L. A. (2001). Two types of GGE biplot for analyzing multienvironmental trial data. Crop Science, 41, 656-663. doi:10.2135/cropsci2001.413656x.

Yan, W. (2001). GGE biplot: a Windows application for graphical analysis of multienvironment trial data and other types of two-way data. Agronomy Journal, 93, 1111-1118. doi:10.2134/agronj2001.9351111x.

Yan, W. (2002). Singular-value partitioning in biplot analysis of multienvironment trial data. Agronomy Journal, 94(5), 990-996. doi:10.2134/agronj2002.0990.

Yan, W., \& Hunt, L. A. (2001). Interpretation of genotype. Crop Science, 41(1), 19 25. doi:10.2135/cropsci2001.41119x.

Yan, W., \& Kang, M. S. (2002). GGE Biplot Analysis: A Graphical Tool for Breeders, Geneticists, and Agronomists. London: CRC Press. doi:10.1201/9781420040371.

Zang, C., Hartl-Meier, C., Dittmar, C., Rothe, A., \& Menzel, A. (2014). Patterns of drought tolerance in major European temperate forest trees: climatic drivers and levels of variability. Global Change Biology, 20(12), 3767-3779. doi:10. $1111 / g c b .12637$.

Zhao, X., Xia, H., Wang, X., Wang, C., Liang, D., Li, K., \& Liu, G. (2016). Variance and stability analyses of growth characters in half-sib Betula platyphylla families at three different sites in China. Euphytica, 208(1), 173-186. doi:10.1007/s10681015-1617-7.

\section{Submit your manuscript to a SpringerOpen ${ }^{\circ}$ journal and benefit from:}

- Convenient online submission

- Rigorous peer review

- Immediate publication on acceptance

- Open access: articles freely available online

- High visibility within the field

- Retaining the copyright to your article

Submit your next manuscript at $>$ springeropen.com 